\title{
RAMBLINGS ON \\ VS SCIENTIFIC STUDY
}

\section{KEITH BARR, 40 Richardson Crescent, Regina, Saskatchewan. S4S 4J3}

This is not a scientific study or project to determine anything, it is only the ramblings on of an old man.

In the fall, I started to feed the magpies in Wascana Park, to see if 1 could get close enough to get a good picture of one ... or wait, to get a picture of the raven that was in the park at this time? I can't remember now. No matter, the raven left before I got a good picture of it and the magpies got most of the tidbits with which I tried to entice the raven.

The tidbits were animal fat that I had cut into small cubes. I got the fat from the local butcher. I told him I wanted it for the birds. I'm not sure he believed me; he most likely thought that I was for the birds!

As is our habit, my wife and I walk around the park almost every morning. During our walk I would drop tidbits when I knew the birds were watching. They were soon coming to within $20 \mathrm{ft}$. of us. I'm not sure if the magpies actually ate any of my offerings or not. I never actually saw them eat any of it. They would pick the tidbit up and fly away to a bush or a tree and hide it under some leaves or in a notch of a tree, then return for seconds, thirds and more until my morning supply ran out.

Like most winters, the snow came, and when I dropped the tidbits they disappeared in the sriow. The birds would scatter the snow with their beaks until they found the treat. Now that the snow has covered the leaves, the magpies are hiding their food in the snow. They are even hiding it in the snow on top of the spruce boughs.

I wonder, do the birds remember where they hid all this food? I know if I want to remember something, I have to make a note of it, but I never remember to do this. I'm quite sure they don't remember where every piece is hidden. Woodpeckers, nuthatches and chickadees must find a lot of their stashes in the trees, while I'm sure mice and voles find the ones on the ground. I never realized I was feeding so many birds and animals.

When the snow got deeper I would place the tidbits on a branch of a tree. The magpies would hop from branch to branch until they were close enough to reach it. Some birds would grab the tidbit and be gone. Others would take the tidbit and remain in the same spot as if daring me to try and take it away from them. Some magpies would come for the handout even if I was only 18 in. away. Some are quite bold, while others are very skittish.

I was not able to convince the birds to meet us at the same place and time everyday, or was it that I slept in too often and I was the one that could not be trained? Whatever the reason, this feeding site did not last long.

All through the winter I carried food for the birds, but with little success. 


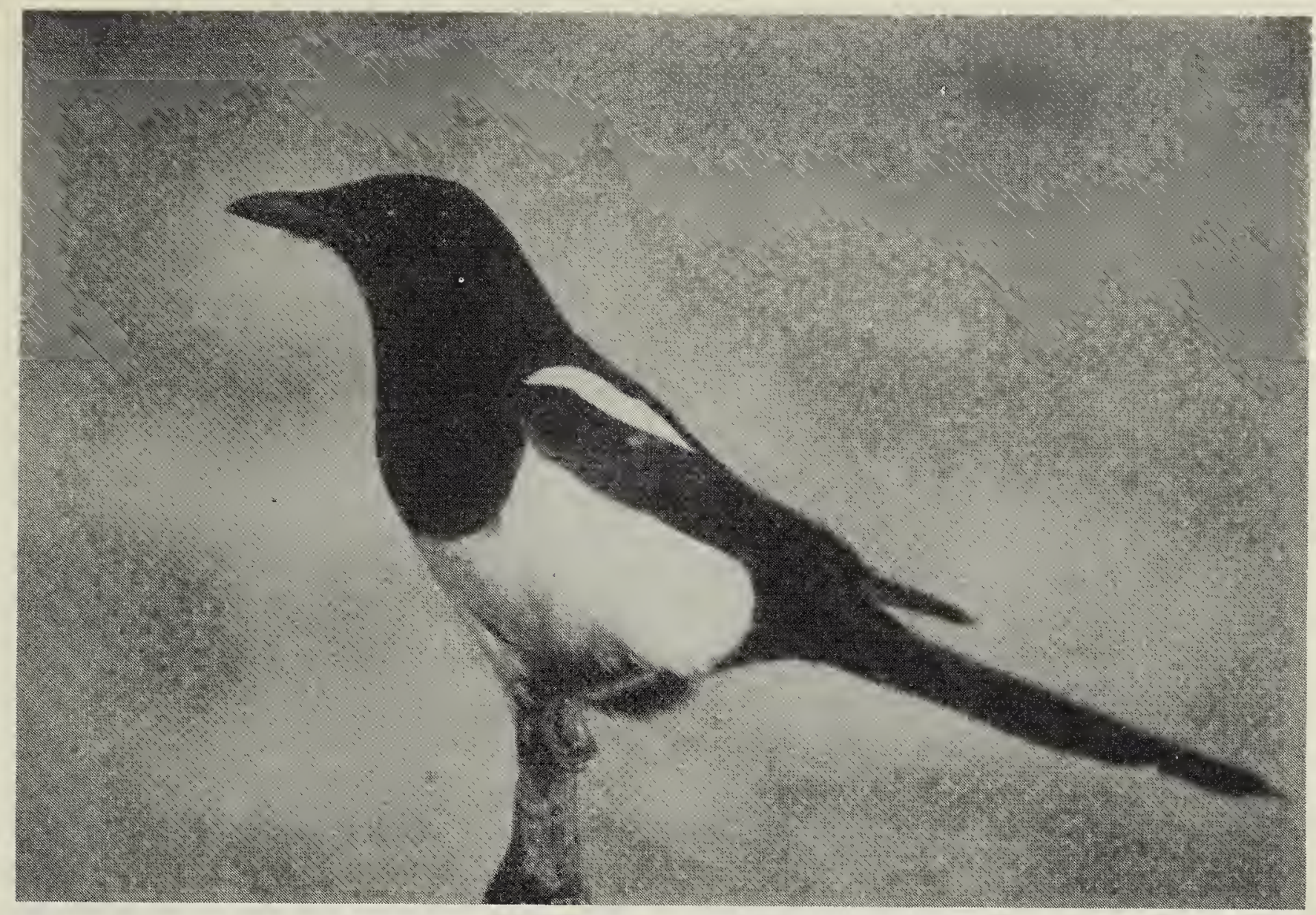

Sure, sometimes I was able to coax a magpie to come fairly close, but most of the time I would have to drop the tidbit and walk some distance away before the bird would come and pick it up. A lot of the time we would not even see a magpie or, if we did, it was at a distance.

In March, in an area where the magpies had been indifferent to us for most of the winter, I started to offer them tidbits and one followed for some distance as I kept offering it tidbits. The next day when we arrived at this area, there were three or four magpies willing to accept our offerings if we would walk about $20 \mathrm{ft}$. away after dropping it on the ground. This went on for a few days. Then one day when we returned, there were four magpies about $200 \mathrm{ft}$. away. They seemed to be squabbling among themselves. On catching sight of us, they flew straight to where we were. cleared off a picnic table and placed the tidbits on the table. The magpies would now allow us to come within 5 $\mathrm{ft}$. of them. I was curious to see how smart these birds were. I put a couple of tidbits on the table and covered each with a leaf. The magpies would fly in, pick off the leaf and take the tidbit, hop to the second leaf, drop the first tidbit, remove the second leaf, pick up the tidbit, then the first and fly off. The magpie is an opportunist. He will take as much as he can get in his beak and is very adept at holding three or four pieces at one time.

We all know the weather in Saskatchewan can change from one extreme to another. Along with this we change our clothing to suit the weather. The magpies still recognized us no matter what we wore, or did they? Would they have come to anyone who happened along at this time? Who knows?

The following day the magpies met 
me about $200 \mathrm{ft}$. from the feeding area. They followed me to the picnic table. I tried to place leaves over the food again, but the wind kept blowing the leaves away, so no tricks today.

The next day, on returning to the picnic table, there were three magpies waiting for us. I covered the tidbits with a leaf again. Two of the birds would remove the leaf and get the tidbit. The third bird sat in a tree about $10 \mathrm{ft}$. away and watched the other birds uncover the food and take it. I even uncovered the tidbits and showed this bird what was there and then covered them again. No response (I think it was out of sight, out of mind). I then placed a tidbit on the table and left it uncovered. This bird came and took the uncovered piece but did not investigate the covered ones. On leaving the picnic table, one of the birds followed us. I saw an old paper cup with the bottom missing. I placed a tidbit on the ground and covered it with the paper cup. The magpie pushed the cup aside and was rewarded with the food.

Another day, arriving at the picnic table there are no birds in sight. We wait a minute or two and, sure enough, here comes a magpie.
Which one, I have no idea; they all look alike to me. WHOA! I just said that I cannot tell one magpie from another, yet a few paragraphs back I was telling you that the magpies recognized me, even when I wore different clothing. Does this mean that the magpies are smarter then I am? Oh well, I have never said that I was as smart as Einstein. I put a few tidbits as well as an unshelled peanut on the table. The magpie takes the peanut and flies a short distance away and is able to open the shell and get the nuts inside.

Why did the magpie take the peanut? Because it was different? Or did he know what it was? He had no problem getting it open and eating the nuts inside. I have often fed unshelled peanuts to chickadees, nuthatches and Blue Jays. What $I$ do not understand is how do these birds know what peanuts are and that they are good to eat. We do not grow peanuts or any other crop that resembles peanuts. These birds do not migrate anywhere, least of all to Georgia, where peanuts grow, so how do they know what they are? As this is an unscientific study that has reached no conclusions, I guess I will never know.

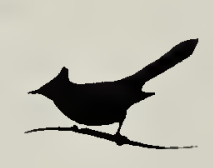

Somewhere in his writings, Thoreau set down that the human ear is not keen enough to catch the first footfalls of returning Spring. Perhaps so. Or perhaps Spring never quite goes away and is always with us to some slight degree. Who knows the first instant when the buds begin to swell on the trees or the very moment when the Skunk Cabbage first wriggles its hooked nose and starts to push up through the debris of the frozen ground? John Keiran. 1947. A cup of sky. Houghton Mifflin, Boston (Krutch \& Eriksson. 1962. A treasury of birdlore. Eriksson, NY. P. 25) 